\title{
Role of the Tree Species Selected in Developing Swampy Forest System for Passive Treatment of Acid Mine Drainage
}

\author{
Ihsan Noor ${ }^{1 *}$, Yudi Firmanul Arifin ${ }^{2,4}$, Bambang Joko Priatmadi ${ }^{3}$ and Akhmad Rizally \\ Saidy $^{3}$, Irdika Mansur ${ }^{5}$ \\ ${ }^{1}$ Mining Study Program, Faculty of Engineering, Lambung Mangkurat University (ULM), \\ Jalan Jenderal Ahmad Yani KM-36, Banjarbaru, South Kalimantan, Indonesia (70714). \\ ${ }^{2}$ Department of Forestry, Faculty of Forestry, ULM. \\ ${ }^{3}$ Department of Soil Science, Faculty of Agriculture, ULM. \\ ${ }^{4}$ Center of Excellence for Innovation, Technology, Commercialization, Management: Forest \\ and Wetland of ULM. \\ ${ }^{5}$ Forestry Faculty, IPB University, Bogor, West Java, Indonesia. \\ * Correspondence Author: ihsan.noor@ulm.ac.id
}

\begin{abstract}
Coal mining is one of economic sector that requires forestry area in Indonesia. Most of coal mining concession are forestry area loan use from the government and during mining operation facing with acid mine drainage (AMD). AMD passive treatment can be integrated with revegetation process that related with better handling of overburden $(\mathrm{OB})$ with potential acid forming (PAF) during reclamation processed. The most expensive methods and uncertainty process are the use of quick lime in treatment of AMD. During operation and preparing mine closure stage need to create the effective one to comply with the regulation. "Swampy Forest (SF) system" is an alternative method of sustainable and naturally process. Selecting the appropriate tree species as a preliminary process to develop a better SF system by batch experiment in the form of a forest constructed wetland. The tree species selected are Nauclea orientalis (lonkida tree) and Melaleuca cajuputi (kayuputih tree) as non-local species then Nauclea subdita (bangkal tree) and Melaleuca leucadendron (galam tree) as local species have been selected. Local species higher in $\mathrm{Fe}$ and $\mathrm{Mn}$ adsorption in $\mathrm{pH}$ of $\mathrm{AMD}<4$ then nonlocal species higher in $\mathrm{Fe}$ and $\mathrm{Mn}$ adsorption on $\mathrm{pH}$ of AMD $>4$ condition.
\end{abstract}

\section{Introduction}

Coal mining is one of economic sector that requires forestry area in Indonesia. Most of coal mining concession are under forestry land (Pratiwi et al., 2021). During operation and postmining stage, coal mining facing with AMD issue (Beauclair et al., 2021) and lower successful level of post mining revegetation (Noor et al., 2019). AMD is one such major issue that occurs in many coal mines with the low $\mathrm{pH}$ value of water in voids of former mining pits (Geller et al., 2013; McCullough \& Schultze, 2018).

Generally, coal mining companies face an AMD expensive treatment if not handling properly. To apply open cut mining methods has a consequence of environmental impact and requires an integrated process both acid mine drainage treatment and successful revegetated. Sustainable AMD treatment is a critical process that can be integrated during mining and 
reclamation process of post mining (Ulrich et al., 2012). Reclamation on post mining is revegetated the area with tree species selected reference with forestry procedure (Permenhut P.60, 2009).

We have developed the SF system consists of selecting organic matter, grass and tree species (Noor et al., 2020). The aim of the present study was to rapidly decides the best tree species to apply of passive treatment in developing the SF system.

\section{Experimental Design}

Batch reactor system applied to carried out the ability of tree species (Liu, 2017; Trepel et al., 2000). This experiment was carried out in the reclamation land ex pit of a coal mining company (PT JBG) in South Kalimantan, Indonesia. The experiment was designed using five treatments with three replications in 15 experiment reactors of $1.2 \mathrm{~m}^{3}$ of acid water each boxes of y: $50 \mathrm{~cm}$ for each reactor (Trepel et al., 2000).

The treatment protocol was to place a layer of overburden soil $(\mathrm{OB})$ in the bottom in each reactor, then treatment with a manure $(\mathrm{MN})$ as an organic fertilizer to support the tree planting process. Then continued drainage of AMD to the reactor. For control was only filled with OB, MN and AMD. Species of tree used in this experiment are Nauclea orientalis (lonkida tree), Nauclea subdita (bangkal tree), Melaleuca leucadendra (galam tree), Melaleuca cajuputi (kayuputih tree). These tree species were considered as a higher hyperaccumulator species and growing better in wet condition, low $\mathrm{pH}$ and higher concentration of $\mathrm{Fe}$ and $\mathrm{Mn}$ as well (Adiloğlu, 2018; Holland et al., 2018).

\section{Experimental Procedure}

The 15 reactors experiments are design of randomly plot according to the treatment code. The batch reactor were filled with the first OB layer of $160 \mathrm{~kg}$ each, then placed on top of it in the form of a second layer, the treatment of organic fertilizer then planted with tree species of treatment, each nine tree (Liu, 2017; Trepel et al., 2000). Each reactor was then allowed to incubation process for seven days. After the incubation process completed will be continued by slowly filling with surface water until the water level each reactor was average height $16 \mathrm{~cm}$ from the top OB layer and let it seven days acclimated process. Then continue by draining all existing water on each reactor via a tap at the bottom and replace with AMD for second acclimation of another seven days process. When the total acclimatization period was completed, all the water in the reactor was replaced again with full of AMD to start entering treatment period (Liu, 2017).

The measurement of water of $\mathrm{pH}$ in each reactor started on day $1^{\text {st }}$ until day $15^{\text {th }}$. The $\mathrm{pH}$ measurement is carried out in the reactor box with a $\mathrm{pH}$ meter. Another parameters measurement is Total Suspended Solid (TSS), Fe, and Mn on the day $15^{\text {th }}$ of treatment period (Kepmen LH 113, 2003)

\section{Data Analysis}

To determine the ability of each parameter in each treatment that was tested by statistical analysis of variance, Duncan's multiple range test and the effectiveness of the percentage of increasing of $\mathrm{pH}$ and reduction in $\mathrm{Fe}, \mathrm{Mn}$, and TSS concentrations by comparing the concentration day $15^{\text {th }}$ to day $1^{\text {st }}$. The selected of tree species is the result of treatment which has parameter values that meet the threshold value according to regulations (Indonesian Minister of the Environment Decree Number 113 of 2003 concerning Wastewater Quality Standards for Mining Activities) that the pH 6-9, TSS $<400 \mathrm{mg} \mathrm{L}^{-1}, \mathrm{Fe}<7 \mathrm{mg} \mathrm{L}^{-1}$ and $\mathrm{Mn}<4 \mathrm{mg} \mathrm{L}^{-1}$ (Kepmen 
LH 113, 2003). To compare Fe and Mn of plant to at soil, determine the bioaccumulation factor (BAF) of Fe or Mn (Anning \& Akoto, 2018; Takarina \& Pin, 2017). The BAF is Fe or Mn concentration in plants / concentration in soil.

$$
B A F=\frac{\text { concentration of Fe or } M n \text { in plants }}{\text { Concentration of Fe or Mn in soil }}
$$

The removal efficiency of each parameter was calculated to determine the potential of $\mathrm{Fe}$ and $\mathrm{Mn}$ uptake of tree species based on following equation (Anning \& Akoto, 2018; Takarina \& Pin, 2017).

$$
\% \text { Removal efficiency }=\frac{(C \text { ini }-C \text { fin })}{C \text { ini }} \times 100
$$

where $\mathrm{C}$ ini represent the initial concentration of metal content, while $\mathrm{C}$ fin signify the final concentration of metal content.

\section{Result and Discussion}

\section{Effect of tree species the changes in $\mathrm{pH}$ of AMD}

Void as a source of AMD had an acid water of average $\mathrm{pH}<4$. The AMD treated with tree species laboratory scale experiments showed the four tree species are significant differences with the control on day $15^{\text {th }}$ as showed on Figure 1.

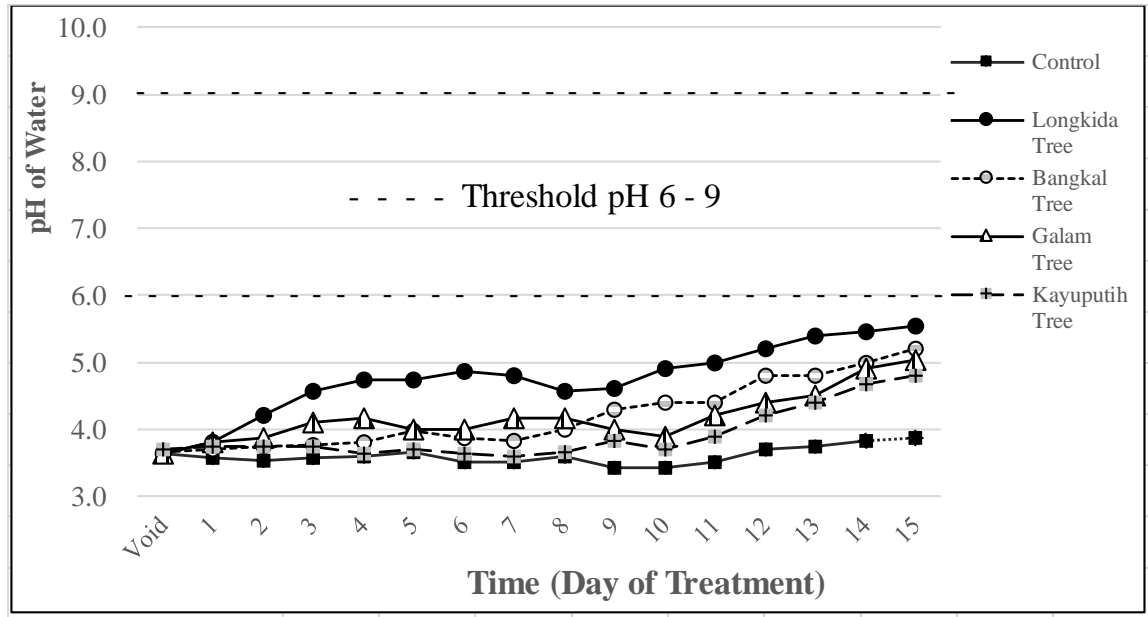

Figure 1. $\mathrm{pH}$ trend of tree species treatment on batch reactor experiment starts on day $1^{\text {st }}$ until day $15^{\text {th }}$.

All tree species treatment showed the $\mathrm{pH}$ of water reduce on day $1^{\text {st }}$ and started increasing from day $2^{\text {nd }}$ to day $15^{\text {th }}$. On the day $15^{\text {th }}$, the lonkida tree showed the highest of $\mathrm{pH}$ was 5.53 that was not significant difference with other tree species of bangkal tree with $\mathrm{pH}$ was 5.20, galam tree was 5.03 and kayuputih tree was 4.80. All tree species are significant difference with control showed almost meet with the $\mathrm{pH}$ threshold of compliance parameter value. The result still was not complying with the threshold, but they had potential to reach it on the other day of treatment considering the trend of their increasing. Applying manure during the tree planting 
process can reduce the acidity as on the same time the tree uptake the heavy metal from the soil or water (Jayalath et al., 2016; Lee et al., 2014).

\section{Effects of tree species treatment on changes in TSS, Fe, and Mn of AMD}

TSS is one of threshold parameter. The results of the TSS observations are presented in Figure 2. The TSS observations on day $1^{\text {st }}$ showed higher than in voids and day $15^{\text {th }}$ higher than day $1^{\text {st }}$. Mostly the value is compliance with the national regulation but reference with the regional one is some not compliance. If compared day $15^{\text {th }}$ to day $1^{\text {st }}$, only kayuputih tree show reduction efficiency is $20.1 \%$ and other tree species treatment show the TSS value is increase. Compared with threshold value, all tree species treatment meets with compliance value of National level is TSS $<400 \mathrm{mg} \mathrm{L}^{-1}$ but if compare with regional level of South Kalimantan compliance of threshold, only bangkal tree and kayuputih tree are the TSS $<200 \mathrm{mg} \mathrm{L}^{-1}$.

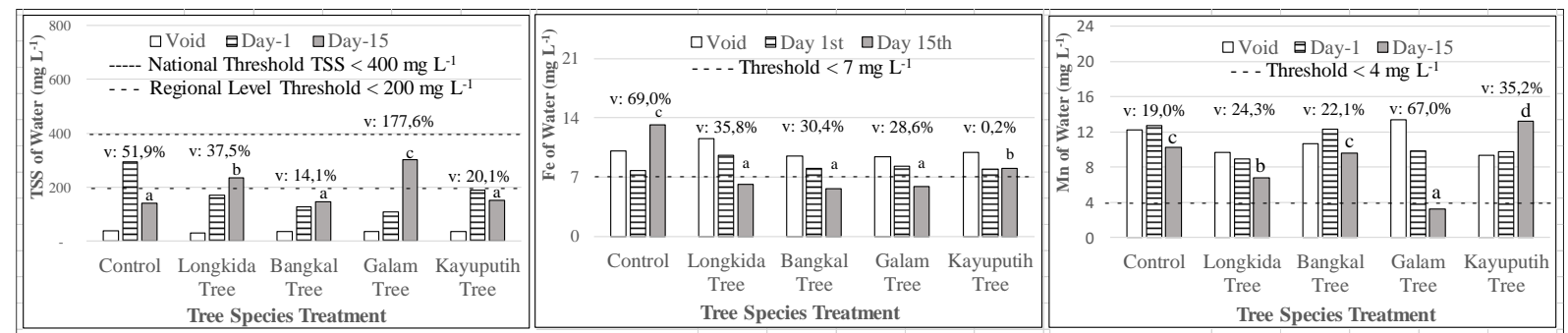

Figure 2. Comparison of TSS, Fe and Mn on void, day $1^{\text {st }}$ and $15^{\text {th }}$ of tree species treatment. The different lowercase letter above the columns indicate significant differences between the treatment and variance (v) is TSS, Fe and Mn reduction efficiency on day $15^{\text {th }}$.

AMD generally has high Fe and Mn content in coal mining sites (Herniwanti et al., 2014). Higher $\mathrm{Fe}$ and $\mathrm{Mn}$ values contribute to non-fulfillment of predetermined water quality standards. Values that exceed the quality standard must be treated so that the value of $\mathrm{Fe}<7$ $\mathrm{mg} \mathrm{L}^{-1}$ and $\mathrm{Mn}<4 \mathrm{mg} \mathrm{L}^{-1}$. Figure 2 shows that all tree species treatments showed a decrease in Fe value on day $15^{\text {th }}$ of water compared to the conditions in the voids or on the day $1^{\text {st }}$. On the day $15^{\text {th }}$ of treatment, all types of treatment trees showed Fe values $<7 \mathrm{mg} \mathrm{L}-1$ except for kayuputih trees. The highest efficiency of Fe reduction on the day 15th was shown by lonkida tree by $35.8 \%$ then bangkal tree by $30.4 \%$, galam trees by $28.6 \%$ and kayuputih tree by $0.2 \%$.

Content of $\mathrm{Mn}$ in water is also higher of $\mathrm{Mn}$ or not compliance. The water treatment also needs to reduce content of Mn. Figure 2 shows the increase of Mn content if compare day $1^{\text {st }}$ to void condition but if compare the day $15^{\text {th }}$ to day $1^{\text {st }}$ indicated the trending decrease. Only the galam tree treatment meets with $\mathrm{Mn}$ value of threshold. The highest efficiency reduction of $\mathrm{Mn}$ on day $15^{\text {th }}$ showed by galam tree is $67.0 \%$ then lonkida tree is $24.3 \%$, bangkal tree is $22.1 \%$, but kayuputih tree increased $35.2 \%$.

\section{Fe and Mn uptake by tree species}

The four species of tree showed their role to uptake the Fe and Mn from the soil that contaminated AMD. On Table 1 showed the result of plant uptake the heavy metal of Fe and Mn figured by the accumulation factor for soil contaminated by heavy metal which all trees species have BAF ratio $>1$. The highest $\mathrm{BAF}$ ratio for Fe is bangkal tree and for $\mathrm{Mn}$ is lonkida tree. The highest of Fe uptake showed on bangkal tree species is $23.56 \mathrm{~g} \mathrm{~kg}^{-1}$ and the lowest 
one is kayuputih tree. For Mn, the highest showed by lonkida tree is $8.03 \mathrm{~g} \mathrm{~kg}^{-1}$ and the lowest one is bangkal tree. Lonkida and kayuputih as not local tree species higher to uptake Fe and $\mathrm{Mn}$ in $\mathrm{pH}>4$ while bangkal and galam as local tree species higher to uptake the Fe and $\mathrm{Mn}$ in $\mathrm{pH}<4$ condition.

Table 1. Total Fe and Mn uptake on day $15^{\text {th }}$. BAF ratio showed in plant higher than in soil.

\begin{tabular}{cccccccccc}
\hline Tree Species & \multicolumn{2}{c}{$\mathrm{Fe}\left(\mathrm{g} \mathrm{kg}^{-1}\right)$} & \multicolumn{2}{c}{$\mathrm{Mn}\left(\mathrm{g} \mathrm{kg}^{-1}\right)$} & \multicolumn{2}{c}{ BAF Ratio } & \multicolumn{2}{c}{ Condition } \\
\cline { 2 - 10 } Treatment & Plant & Soil & Plant & Soil & Fe & \multicolumn{1}{c}{$\mathrm{Mn}$} & $\mathrm{pH}<4$ & $\mathrm{pH}>4$ \\
\hline Longkida & 20.63 & 9.60 & 8.03 & 0.17 & 2.15 & 46.99 & - & Higher \\
Bangkal & 23.56 & 9.59 & 0.95 & 0.12 & 2.46 & 7.95 & Higher & - \\
Galam & 16.71 & 7.07 & 1.14 & 0.07 & 2.36 & 17.21 & Higher & - \\
Kayuputih & 12.43 & 9.86 & 3.05 & 0.23 & 1.26 & 13.49 & - & Higher \\
\hline
\end{tabular}

\section{Role of Tree Species on AMD Treatment}

On this experiment, each tree species has been shown their performance to increase the $\mathrm{pH}$ and reducing the TSS, Fe and Mn of AMD. Each tree species has role to reduce the Fe and Mn mostly higher in AMD. The reducing of Fe and $\mathrm{Mn}$ on tree species treatment to confirm the previous research of constructed wetland that longida tree and kayuputih tree can adsorb $\mathrm{Fe}$ and Mn (Rahmatia et al., 2019) (Tuheteru et al., 2016). Tree species have ability to adapt or to tolerate the heavy metal (Dhir, 2013; Ford, 2003) to transfer oxygen to media by root (Skousen et al,. 2019) and the tree species can survival in wet condition (Irhamni et al., 2018). The tree species adapted by showing better biomass production and efficiency to reduce the Fe and $\mathrm{Mn}$ (Tuheteru et al., 2016) that can be indicated by the grass and tree species accumulate potential (Karathanasis \& Johnson, 2003).

Phytoremediation is a process that helps the absorption of metals by plants which depends on the ability of roots to limit the mobility of contaminants and their availability in the soil through binding, deposition, or reduction of complexity (Glick, 2003). Types of tree can hold metal at the root or collect and localize metal on cell vacuoles (Prihatini et al., 2015). Tree species of hyperaccumulator are widely used in Phyto stabilization which is part of the phytoremediation process considering its rapid growth and extensive root system (Dhir, 2013; Yan et al., 2020). Tree species can absorb heavy metals through their roots and shoot through a fairly high transpiration process in the rooting area which ultimately has the role of limiting the movement of heavy metals in the soil (Skousen et al., 2019). The $\mathrm{pH}$ rooting areas are changed by some root exudates and help the process of deposition of heavy metals, limit their availability and reduce the level of poisoning (Dhir, 2013; Hidayati, 2013).

\section{Tree species selected for Swampy Forest System}

"Swampy Forest (SF) system" is a new concept of passive treatment which is defined as post-mining reclamation by combination of organic matter treatment, planting of undergrowth of certain types of grass and woody trees that are able to live in wet conditions, low $\mathrm{pH}$ and high heavy metal concentrations with constructed wetland reference concept (Noor et al., 2020). The tree species selected will be combined with organic matter and grass species those selected on the other experiment as the basic media of SF system. Concepts of forest constructed wetlands are naturally for wastewater treatment systems, which are designed to utilize the natural purification processes involving wetland plants, substrates, and the associated microbes 
(Cheng et al., 2018; Hlihor et al., 2017). Bangkal tree and galam tree can adsorb higher Fe and $\mathrm{Mn}$ in condition $\mathrm{pH}<4$ and lonkida tree and kayuputih higher to adsorb $\mathrm{Fe}$ and $\mathrm{Mn}$ in $\mathrm{pH}>4$ (Kumar et al., 2019).

\section{Conclusion}

This study provides evidence of the tree species selected have ability to adsorb the Fe and Mn from the soil by phytoremediation process. The tree species has roles to comply with the threshold both individually and together with others. The conclusions from the experiments described revealed that the four tress species selected of lonkida tree, bangkal tree, galam tree, kayuputih tree have role to adsorb Fe and $\mathrm{Mn}$ in different condition. All tree species will be applied in SF system to treat the water parameter that mostly are not comply and change it to be comply parameter before releasing to public water bodies.

\section{Acknowledgments}

This research is the Swampy Forest (SF) System and thank all supported by:

1. PT JBG for area research facility.

2. Mine Closure Research Center of Lambung Mangkurat University

3. PT Swampy Forest Indonesia (Acid Mine Drainage Solution Consultant), South Kalimantan, Indonesia (pt.swampy.forest@gmail.com)

\section{References}

[1] Adiloğlu, S. (2018). Heavy Metal Removal with Phytoremediation. Advances in Bioremediation and Phytoremediation, pp. 115-126. https://doi.org/10.5772/intechopen.7

[2] 0330

[3] Anning, A. K., \& Akoto, R. (2018). Assisted phytoremediation of heavy metal contaminated soil from a mined site with Typha latifolia and Chrysopogon zizanioides. Ecotoxicology and Environmental Safety. https://doi.org/10.1016/j.ecoenv.2017.10.014

[4] Beauclair, N., Masindi, V., Msagati, T. A. M., \& Memory, T. (2021). The treatment of acid mine drainage using vertically flowing wetland: Insights into the fate of chemical species. Minerals, 11(5), 1-24. https://doi.org/10.3390/min11050477

[5] Cheng, G., Li, Q., Su, Z., Sheng, S., \& Fu, J. (2018). Preparation, optimization, and application of sustainable ceramsite substrate from coal fly ash/waterworks sludge/oyster shell for phosphorus immobilization in constructed wetlands. Journal of Cleaner Production. https://doi.org/10.1016/j.jclepro.2017.12.102

[6] Dhir, B. (2013). Phytoremediation: Role of aquatic plants in environmental clean-up. In Phytoremediation: Role of Aquatic Plants in Environmental Clean-Up. https://doi.org/10.

[7] 1007/978-81-322-1307-9

[8] Ford, K. L. (2003). Passive Treatment Systems for Acid Mine Drainage. National Science and Technology Center. Technical Note 409, U.S. Department of the Interior, Bureau of Land Management, 19. https://doi.org/BLM/ST/ST-02/001+3596

[9] Geller, W., Schultze, M., Kleinmann, R., \& Wolkersdorfer, C. (2013). Acidic pit lakes: The legacy of coal and metal surface mines. Environmental Science and Engineering (Subseries: Environmental Science). https://doi.org/10.1007/978-3-642-29384-9

[10] Glick, B. R. (2003). Phytoremediation: Synergistic use of plants and bacteria to clean up the environment. Biotechnology Advances, 21, 383-393. 
https://doi.org/10.1016/S0734-9750(03)00055-7

[11] Halverson, N. V. (2004). Review of Constructed Subsurface Flow vs. Surface Flow Wetlands. In US Department of Energy - Westinghouse Savannah River Company Report (No. WSRC-TR-2004-00509).

[12] Herniwanti, Priatmadi, J. B., Yanuwiadi, B., \& Soemarno. (2014). Characteristics of acid mine water. International Journal of ChemTech Research.

[13] Hidayati, N. (2013). Mekanisme fisiologis tumbuhan hiperakumulator logam berat. Jurnal Teknik Lingkungan, 14(2), 75-82.

[14] Hlihor, R. M., Gavrilescu, M., Tavares, T., Favier, L., \& Olivieri, G. (2017). Bioremediation: An Overview on Current Practices, Advances, and New Perspectives in Environmental Pollution Treatment. BioMed Research International, 2017. https://doi.org/10.1155/2017/

[15] 6327610

[16] Holland, J. E., Bennett, A. E., Newton, A. C., White, P. J., McKenzie, B. M., George, T. S., ... Hayes, R. C. (2018). Liming impacts on soils, crops and biodiversity in the UK: A review. Science of the Total Environment, 610-611(August), 316-332. https://doi.org/10.1016/j.sc

[17] itotenv.2017.08.020

[18] Irhamni, Pandia, S., Purba, E., \& Hasan, W. (2018). Kajian Akumulator Beberapa Tumbuhan Air dalam Menyerap Logam Berat secara Fitoremediasi. Jurnal Serambi Engeneering. https://doi.org/10.5281/ZENODO.400012

[19] Jayalath, N., Mosley, L. M., Fitzpatrick, R. W., \& Marschner, P. (2016). Addition of organic matter influences $\mathrm{pH}$ changes in reduced and oxidised acid sulfate soils. Geoderma. https://doi.org/10.1016/j.geoderma.2015.08.012

[20] Karathanasis, A. D., \& Johnson, C. M. (2003). Metal Removal Potential by Three Aquatic Plants in an Acid Mine Drainage Wetland. Mine Water and the Environment, 22, 22-30. https://doi.org/10.1007/s102300300004

[21] Kepmen LH 113. (2003). Keputusan Menteri Negara Lingkungan Hidup Republik Indonesia Nomor 113 Tahun 2003 Tentang Baku Mutu Air Limbah Bagi Usaha Dan Atau Kegiatan Pertambangan Batu Bara. Menteri Negara Lingkungan Hidup Republik Indonesia.

[22] Kumar, V., Singh, J., \& Kumar, P. (2019). Heavy metals accumulation in crop plants: Sources, response mechanisms, stress tolerance and their effects. Contaminants in Agriculture and Environment: Health Risks and Remediation, 249404, 38-57. https://doi.org/10.26832/ae

[23] sa-2019-cae-0161-04

[24] Lee, E., Shon, H. K., \& Cho, J. (2014). Role of wetland organic matters as photosensitizer for degradation of micropollutants and metabolites. Journal of Hazardous Materials. https://doi.org/10.1016/j.jhazmat.2014.05.001

[25] Liu, S. (2017). Batch Reactor. In Bioprocess Engineering. https://doi.org/10.1016/b978-0-444-63783-3.00004-6

[26] Mawaddah, M., Mansur, I., \& Saria, L. (2012). Pertumbuhan Kayu Putih (Melaleuca leucadendron Linn.) dan Longkida (Nauclea orientalis Linn.) pada Kondisi Tergenang Air Asam Tambang. Jurnal Silvikultur Tropika, 3(2), 71-75.

[27] McCullough, C. D., \& Schultze, M. (2018). Engineered river flow-through to improve mine pit lake and river values. Science of the Total Environment. https://doi.org/10.1016/j.scitotenv 
[28] 2018.05 .279

[29] Noor, I., Arifin, Y. F., Priatmadi, B. J., \& Saidy, A. R. (2020). Development of the Swampy forest system for passive treatment of acid mine drainage during post mining land reclamation: A new concept review. Ecology, Environment \& Conservation, 26(2), 901-909.

[30] Noor, I., Udiansyah, U., Priatmadi, B. J., \& Winarni, E. (2019). Evaluation of Degraded Land Management on Soil Physical Properties of Coal Post Mining Revegetation Land. EnviroScienteae, 15(3), 441. https://doi.org/10.20527/es.v15i3.7438

[31] Permenhut P.60. (2009). Peraturan Menteri Kehutanan Nomor: P.60/Menhut-II/2009 Tentang Pedoman Penilaian Keberhasilan Reklamasi Hutan. Menteri Kehutanan Republik Indonesia.

[32] Pratiwi, Narendra, B. H., Siregar, C. A., Turjaman, M., Hidayat, A., Rachmat, H. H., Susilowati, A. (2021). Managing and reforesting degraded post-mining landscape in Indonesia: A review. Land, 10(6). https://doi.org/10.3390/land10060658

[33] Prihatini, N. S., Priatmadi, B. J., Masrevaniah, A., \& Soemarno. (2015). Performance of the Horizontal Subsurface-Flow Constructed Wetlands with Different Operational Procedurs. International Journal of Advances in Engineering \& Technology.

[34] Rahmatia, C., Hilwan, I., Mansur, I., \& Noor, I. (2019). Analysis of Constructed Swamp Forest Vegetation as A Phitoremediation Agent in Coal Mining, South Kalimantan. Media Konservasi, 24(1), 29-39. https://doi.org/10.29244/medkon.24.1.29-39

[35] Skousen, J., Zipper, C. E., McDonald, L. M., Hubbart, J. A., \& Ziemkiewicz, P. F. (2019). Sustainable reclamation and water management practices. In Advances in Productive, Safe, and Responsible Coal Mining. https://doi.org/10.1016/b978-0-08101288-8.00015-8

[36] Takarina, N. D., \& Pin, T. G. (2017). Bioconcentration Factor (BCF) and Translocation Factor (TF) of Heavy Metals in Mangrove Trees of Blanakan Fish Farm. Makara Journal of Science, 21(2). https://doi.org/10.7454/mss.v21i2.7308

[37] Trepel, M., O’Dall, M., Cin, L. D., De Wit, M., Opitz, S., Palmen, L., Jorgensen, S.-E. (2000). Models for wetland planning, design and management. EcoSys Bd.

[38] Tuheteru, F. D., Kusmana, C., Mansur, I., Iskandar, \& Tuheteru, E. J. (2016). Potential of lonkida (Nauclea orientalis L.) for phytoremediation of acid mined drainage at PT. bukit asam Tbk. (persero), Indonesia. Research Journal of Botany, 11(1-3), 9-17. https://doi.org/10.3923/rjb.2016.9.17

[39] Ulrich, K. U., Bethge, C., Guderitz, I., Heinrich, B., Neumann, V., Nitsche, C., \& Benthaus, F. C. (2012). In-Lake Neutralization: Quantification and Prognoses of the Acid Load into a Conditioned Pit Lake (Lake Bockwitz, Central Germany). Mine Water and the Environment. https://doi.org/10.1007/s10230-012-0206-4

[40] Yan, A., Wang, Y., Tan, S. N., Mohd Yusof, M. L., Ghosh, S., \& Chen, Z. (2020). Phytoremediation: A Promising Approach for Revegetation of Heavy Metal-Polluted Land. Frontiers in Plant Science, 11(April), 1-15. https://doi.org/10.3389/fpls.2020.00359 